\title{
EFEKTIVITAS PENEGAKAN HUKUM TINDAK PIDANA PERKOSAAN DARI PUTUSAN HAKIM DIHUBUNGKAN DENGAN UNDANG - UNDANG NO 13 TAHUN 2006 TENTANG PERLINDUNGAN SAKSI DAN KORBAN
}

\author{
Oleh: \\ Eigen Justisi \\ eigen.justisi@ubpkarawang.ac.id
}

\begin{abstract}
ABSTRAK
Masalah kekerasan seksual di Indonesia, khususnya terhadap wanita dan anak perlu mendapat perhatian lebih intensif dan serius lagi. Hal ini mengingat terdapat kecenderungan bahwa korban wanita dan anak sering terabaikan oleh lembagalembaga kompeten dalam system peradilan pidana, yang seharusnya memberikan perhatian dan perlindungan yang cukup berdasarkan hukum. Dalam penelitian ini peneliti menggunakan metode pendekatan sosiologi hukum yaitu pendekatan yang menganalisis tentang bagaimana reaksi dan interaksi yang terjadi ketika sistem norma itu bekerja di dalam masyarakat yang berkaitan dengan efektivitas penegakan hukum tindak pidana perkosaan dari putusan hakim dihubungkan dengan Undang-Undang No 13 Tahun 2006 tentang perlindungan saksi dan korban. Berdasarkan penelitian yang dilakukan, bahwa pemberian hukuman pidana hanya dibatasi dengan maksimal berdasarkan ketentuan undang-undang. Oleh karena tidak adanya batas minimal, maka dalam praktiknya pemberian hukuman dalam kasus perkosaan sangat jauh dari harapan korban. Tak jarang hakim hanya memberikan hukuman misalnya, 5 tahun/ 8 tahun penjara.
\end{abstract}

Kata kunci: efektivitas, perkosaan, korban, hakim 


\section{EFFECTIVENESS OF LAW ENFORCEMENT CRIME OF RAPE OF COURT DECISIONS LINKED WITH LAW NUMBER 13 OF 2006 ON PROTECTION OF WITNESSES AND VICTIMS \\ ABSTRACT}

The problem of sexual violence in Indonesia, especially against women and children need more intensive attention and serious again. This is because there is a tendency that the victims women and children are often neglected by the competent institutions in the criminal justice system, which should provide sufficient attention and protection under the law. In this study, researchers used a method of approach to the sociology of law that is the approach that analyzes of how the reactions and interactions that occur when a system of norms at work in the community with regard to the effectiveness of law enforcement of the criminal act of rape of a verdict is connected by Act No. 13 of 2006 concerning protection of witnesses and victims. Based on the research conducted, that the provision of criminal penalties is limited to the maximum under the terms of the law. Hence the absence of a minimum limit, then in practice the provision of punishment in cases of rape is very far from the expectations of victims. Not infrequently judges only impose penalties, for example, 5 years $/ 8$ years in prison.

Keywords: effectiveness, rape, vicims, judges. 


\section{PENDAHULUAN}

\section{A. LATAR BELAKANG PENELITIAN}

Dalam pengamatan nampak gejala bahwa semakin modern suatu masyarakat semakin sekuler disertai ketidakpastian di bidang hukum, moral, norma, nilai dan etika kehidupan. Ketidakpastian ini merupakan sumber stress bagi warga masyarakat dan muncul gejala/penyakit psikososial yang dikenal dengan istilah the agony of modernization", yaitu azab sengsara karena modernisasi yang salah satu wujudnya adalah tindak kejahatan seksual (perkosaan dan pelecehan seksual).

Korban kejahatan seksual tidak hanya wanita dewasa, tetapi juga mereka yang masih dibawah umur (“child sexual abuse”). Para korban kejahatan seksual ini tidak hanya akan menderita akibat trauma fisik (misalnya kehilangan virginitas atau cedera tubuh), namun terutama sekali akan menderita stress mental yang amat berat bahkan bisa seumur hidup, yaitu apa yang dinamakan stress pasca trauma. Pada dasarnya kejahatan seksual itu lebih merupakan trauma psikis daripada trauma fisik. Tidak jarang pelaku kejahatan seksual sampai membunuh korbannya guna menghindari kesaksiaan.

Masalah kekerasan seksual di Indonesia, khususnya terhadap wanita dan anak perlu mendapat perhatian lebih intensif dan serius lagi. Hal ini mengingat terdapat kecenderungan bahwa korban wanita dan anak sering terabaikan oleh lembagalembaga kompeten dalam sistem peradilan pidana, yang seharusnya memberikan perhatian dan perlindungan yang cukup berdasarkan hukum. Hal tersebut tidak 
seharusnya terjadi, sebab bagaimanapun korban tetap mempunyai hak untuk diperlakukan adil dan dilindungi hak-haknya ${ }^{1}$.

Berdasarkan hasil laporan dari Komisi Nasional Perempuan (Komnas Perempuan) Perempuan kasus perkosaan dari tahun 2013, terdapat sebanyak 49 kasus perkosaan di Indonesia ${ }^{2}$.

Karakteristik utama dari tindak perkosaan adalah bahwa perkosaan terutama bukan ekspresi agresivitas dari seksualitas akan tetapi merupakan ekspresi seksual dari suatu (kekerasan) agresivitas (sexual expression of aggression). Bahkan ada yang mengatakan perkosaan termasuk kategori "sexually assaultive bahvior" (Kadish, 1983:1355) atau “sexual coercion” (Felson, 1993:223). Mengacu pada karakteristik utama tersebut maka dapat dikembangkan beberapa karakteristik umum perkosaan sebagai berikut:

1. Agresivitas merupakan sifat yang melekat pada setiap tindak perkosaan;

2. Motivasi kekerasan lebih menonjol dibandingkan dengan motivasi seksual semata-mata;

3. Secara psikologis, tindak perkosaan lebih banyak mengandung masalah kontrol dan kebencian dibandingkan dengan hawa nafsu (Passion) dan keinginan semata-mata (desire);

4. Oleh karena tindak perkosaan merupakan pencerimanan seksual dari agresivitas (Kekerasan) maka tindak perkosaan dapat dibedakan kedalam tiga bentuk, yaitu : (a). anger rape, (b). power rape, (c). Sadistic rave.

\footnotetext{
${ }^{1}$ Mien Rukmini, Aspek Hukum Pidana dan Kriminologi, PT Alumni, Bandung, 2006, hlm 1

${ }^{2}$ Catatan Tahunan Komnas Perempuan, hlm 20
} 
Sesungguhnya ketiga bentuk tindak perkosaan ini berasal dari tiga bentuk agression itu sendiri, yaitu: (1). Dalam bentuk anger dan violation, (2). Dalam bentuk control dan domination dan (3) dalam bentuk pengalaman erotis.

\section{B. IDENTIFIKASI MASALAH}

Sehubungan dengan uraian di atas, terdapat masalah-masalah yang menarik untukdibahas, yang diidentifikasikan sebagai berikut:

1. Mengapa putusan/vonis hakim tidak dapat memberikan putusan/vonis maksimal terhadap pelaku perkosaan ?

2. Upaya apakah yang harus dilakukan oleh penegak hukum agar penegakan hukum tindak pidana perkosaan menjadi efektif dalam melindungi saksi korban?

\section{METODE PENELITIAN}

Spesifikasi Penelitian Penelitian yang digunakan deskriptif analitis, yaitu menggambarkan permasalahan-permasalahan yang menjadi objek penelitian yang berkaitan dengan masalah serta pengaturan perundang-undangan yang berkaitan dengan Efektivitas Penegakan Hukum Tindak Pidana Perkosaan Dari Putusan Hakim Dihubungkan Dengan Undang-undang No 13 Tahun 2006 tentang Perlindungan Saksi dan Korban. Metode Pendekatan Pendekatan yang digunakan dalam penelitian ini menggunakan pendekatan sosiologi hukum yaitu pendekatan yang menganlisis tentang bagaimana reaksi dan interaksi yang terjadi ketika sistem norma itu bekerja di dalam masyarakat. Data lapangan. Peneliti dalam hal ini akan melakukan penelitian di lembaga-lembaga yang terkait seperti Kepolisian, Kejaksaan, Pengadilan, Lembaga Perlindungan Saksi dan Korban, Komnas Perempuan dan masyarakat. Studi lapangan 
dilakukan dalam tujuan untuk mendapatkan data primer sebagai penunjang data sekunder. Teknik Pengumpul Data dengan studi dokumen, wawancara, observasi dan kuesioner.

\section{HASIL DAN PEMBAHASAN}

\section{A. Kajian Terhadap Putusan/Vonis Hakim yang Tidak Dapat Memberikan Putusan/Vonis Maksimal Terhadap Pelaku.}

Putusan hakim merupakan mahkota dan puncak dari suatu perkara yang sedang diperiksa dan diadili oleh hakim tersebut. Oleh karena itu, tentu saja hakim dalam membuat putusan harus memperhatikan segala aspek di dalamnya, mulai dari perlunya kehati-hatian, dihindari sedikit mungkin ketidakcermatan, baik yang bersifat formal maupun materil sampai dengan adanya kecakapan teknik membuatnya. Jika hal-hal negatif tersebut dapat dihindari, tentu saja diharapkan dalam diri hakim hendaknya lahir, tumbuh dan berkembang adanya sikap atau sifat kepuasaan moral jika kemudian putusan yang dibuatnya itu dapat menjadi tolak ukur perkara yang sama atau dapat menjadi bahan referensi bagi kalangan teoritisi maupun praktisi hukum serta kepuasan nurani tersendiri jika putusannya dikuatkan dan tidak dibatalkan pengadilan yang lebih tinggi. ${ }^{3}$

Kalau seorang hakim akan menjatuhkan suatu putusan, maka ia akan selalu berusaha agar putusannya nanti seberapa mungkin dapat diterima masyarakat, setidaktidaknya berusaha agar lingkungan orang yang akan dapat menerima putusannya seluas mungkin. Hakim akan merasa lebih lega manakala putusannya dapat memberikan kepuasan pada semua pihak dalam suatu perkara, dengan memberikan alasan-alasan atau pertimbangan-pertimbangan yang sesuai dengan nilai-nilai kebenaran dan keadilan.

\footnotetext{
${ }^{3}$ Achmad Rifai, Penemuan Hukum Oleh Hakim Dalam Perspektif Hukum Progresif, Sinar Grafika, 2011, Jakarta, hlm 94
} 
Dengan melihat beberapa contoh penjatuhan putusan/vonis hakim pada Putusan Banding No. 202/Pid.B/2013/PN.Dpk selama 8 (delapan) tahun penjara dan Putusan Pengadilan Negeri Karawang No: 11/Pid.B/ 2014/PN.Krw selama 5 (lima) tahun penjara.

Hukum berfungsi sebagai perlindungan kepentingan manusia. Agar kepentingan manusia terlindungi, hukum harus dilaksanakan. Pelaksanaan hukum dapat berlangsung secara normal, damai, tetapi dapat terjadi juga karena pelanggaran hukum. Dalam hal ini hukum yang telah dilanggar itu harus ditegakkan. Melalui penegakan hukum inilah hukum ini menjadikan kenyataan. Dalam menegakkan hukum ada tiga unsur yang selaluharus diperhatikan, yaitu kepastian hukum (Rechtssicherheit), kemanfaatan (Zweckmassigkeit) dan keadilan (Gerechtigkeit). Hukum harus dilaksanakan dan ditegakkan. Setiap orang mengharapkan dapat ditetapkannya hukum dalam hal terjadi peristiwa konkrit. Bagaimana hukumnya itulah yang harus berlaku; pada dasarnya tidak dibolehkan menyimpang; fiat justitia et pereat mundus (meskipun dunia ini runtuh hukum harus ditegakkan). Itulah yang diinginkan oleh kepastian hukum. Kepastian hukum merupakan perlindungan yustisiable terhadap tindakan sewenang-wenang, yang berarti bahwa seseorang akan dapat memperoleh sesuatu yang diharapkan dalam keadaan tertentu. Masyarakat mengharapkan adanya kepastian hukum, karena dengan adanya kepastian hukum masyarakat akannlebih tertib. Hukum bertugas menciptakan kepastian hukum karena bertujuan ketertiban masyarakat. $^{4}$

\footnotetext{
${ }^{4}$ Soerjono Soekanto, Faktor-faktor yang Mempengaruhi Penegakan Hukum, PT. Raja Grafindo Persada, Jakarta, 2013, hlm 25
} 


\section{B. UPAYA PENEGAK HUKUM UNTUK MELINDUNGI SAKSI DAN KORBAN DARI TINDAK PIDANA PERKOSAAN}

Istilah penegakan hukum dibedakan dari istilah penegakan keadilan walaupun idealnya dua hal tersebut bisa bersatu padu dalam satu tujuan, namun terminologi penegakan keadilan memiliki dimensi yang lebih luas dari sekedar menegakkan hukum hal ini sebagaimana dikemukakan oleh Antonius Sudirman bahwa hukum tidak dapat terisolasi dari lingkungan sosial sehingga terbukalah kemungkinan bagi hakim untuk menggunakan hati nuraninya untuk menilai perundang-undangan yang ada agar dapat diterapkan pada kasus-kasus yang konkret. Untuk maksud itu dapat diwujudkan melalui penfasiran dan konstruksi hukum. Hal ini dilakukan untuk menghindari dan mencegah penerapan hukum berdasarkan bunyi undang-undang semata yang sering dimanfaatkan untuk melindungi kaum yang kuat dan mengorbankan kaum yang lemah. 5

Dalam menjalankan tugasnya melayani para pencari keadilan, polisi berada pada lapisan terdepan dan menjadi pihak yang pertama kali berhadapan dengan para pencari keadilan. Posisi menjadi sangat strategis, karena dia dapat menggunakan diskresi, bila dia mau. Diskresi ini dapat berbentuk, misalnya upaya penggunaan peraturan perundang-undangan baru, yang selanjutnya dapat menumbuhkan inisiatif dan terobosan baru dalam proses pengambilan keputusan. Penggunaan diskresi yang dimaksud adalah semata-mata demi terwujudnya keadilan bagi korban perempuan. Penting untuk dipahami juga bahwa tidak berarti bahwa petugas kepolisian laki- laki tidak dapat sensistif gender dan tidak berarti juga semua petugas wanita sensitif gender. Penugasan polisi, baik polisi laki-laki maupun polwan di kepolisian hendaknya selain untuk membuat korban yang kebanyakan berjenis kelamin perempuan merasa nyaman melapor juga disertai dengan pembekalan pelatihan gender dan mekanisme

${ }^{5}$ Darmoko Yuti Witanto, Arya Putra Negara Kutawaringin Diskresi Hakim. CV Alfabeta, Bandung 2013. hlm 19 
penanganan kasus khusus (perkosaan, pencabulan, KDRT) Dalam melaksanakan tugas sebagai JPU, seorang penegak hukum bertindak tidak hanya mewakili negara dalam menegakkan hukum dan mengajukan tuntutan pidana kepada terdakwa. Akan tetapi juga sebagai wakil dari korban. Ternyata, praktik dan teori dapat berbeda. Terjadi dalam satu kasus, JPU sama sekali tidak dapat mengakomodasi kepentingan korban. JPU tidak memilki perspektif korban, apalagi sensitifitas gender. Dalam kasus-kasus yang dipantau dan diteliti, ditemukan juga masih banyak JPU yang bersifat positivistik. Penyusunan surat dakwaan, sebatas mempergunakan format rencana dakwaan yang sudah ada dan tinggal dikaitkan saja dengan pasal-pasal dalam KUHP. Dari kasuskasus yang dipantau, terdapat kesulitan menemukan JPU yang berperspektif gender sekalipun JPU tersebut perempuan.

Dialektika antara hukum dan masyarakat terjadi dalam kerangka dialektika transformatif. Artinya, bahwa dialektika antara hukum dan masyarakat senantiasa berlangsung secara dinamis mengikuti perkembangan dan kebutuhan zaman. Sebagai contoh, pada masa lalu, hukum hanya dipandag mengatur tentang perikatan yang menghadirkan pihak-pihak dalam satu tempat dan slaing berhadap-hadapan untuk mengutarakan maksudnya secara verbal. Seiring dengan perkembangan zaman dan teknologi yang kian canggih menereobos batas ruang dan waktu, perikatan tidak lagi hanya dilakukan secara konvensional, melainkan dapat dilakukan natar daerah, bahkan antar negara tanpa harus mempertemukan secra fisik pihak-pihak yang melakukan perikatan. ${ }^{6}$

Situasi tersebut menuntut adanya transformasi (perubahan) baik dalam system maupun dalam operasionalisasi hukum. Hukum tidak lagi hanya boleh mengatur tentang perikatan yang dilakukan secara konvensional, melainkan juga harus mengatur hal-hal lain yang menerobos tradisi konvensional tersebut.

Berdasarkan ketentuan diatas upaya yang harus dilakukan oleh aparat penegak hukum khususnya seorang hakim yaitu Peranan hakim dalam penemuan hukum. Proses menemukan hukum tidak dimaknai bahwa hukum sedang menjalankan proses

\footnotetext{
${ }^{6}$ M Natsir Asnawi, Hermeneutika Putusan Hakim, UII Press, Yogyakarta, hlm 115
} 
pembentukan undang-undang sebagaimana tugas dan kewenangan seorang legislator, namun fungsi penemuan hukum itu tidak lain untuk mencari dan menemukan makna dan arti hukum yang sebenarnya karena makna hukum itu tidak selalu tersurat secara tekstual dalam rumusan undang-undang. Hukum dalam pengertian formil adalah kumpulan tulisan-tulisan dalam sebuah kertas yang bernama undang-undang atau peraturan perundang-undangan lainnya. Pengertian hukum secara eksplisit tidak lain adalah apa yang tertulis dalam setiap rumusan undang-undang, namun untuk menemukan makna implisit perlu adanya proses pemikiran dn kontemplasi, sehingga apa yang dikehendaki oleh pembentuk undnag- undang dapat tercapai, meskipun tidak selalu diartikan bahwa hakim hanya sekedar menjalankan kehendak dari para pembentuk undang-undang tanpa ada pertimbangan kemanfaatan atas penerapan hukum itu sendiri.

Setiap peraturan perundang-undangan yang dilahirkan selalu akan tertinggal oleh dinamika sosial di masyarakat. Undang-undang dibentuk dan dilahirkan mengikuti kondisi hukum dan masyarakat pada saat itu, sehingga dalam praktiknya banyak aturan yang sudah tidak sesuai lagi dengan kondisi sosial yang ada. Dalam menghadapi gejala seperti itu hakim tidak dapat berpangku tangan dan menutup mata, namun dituntut harus dpaat memberikan solusi yang konstruktif bagi implementasi hukum dalam konteks perubahan sosial yang salah satunya dengan menggunakan metode penemuan-penemuan hukum (rechtvinding). 


\section{PENUTUP}

Berdasarkan analisis yang telah diuraikan pada bagian sebelumnya, maka dapat ditarik kesimpulan sebagai berikut :

1. Didalam menjalankan tugasnya seorang penegak hukum bertindak tidak hanya mewakili negara dalam menegakkan hukum akan tetapi juga sebagai wakil dari korban. Hakim dalam budaya hukum di Indonesia merupakan salah satu pihak yang diharapkan dapat menjadi agen perubahan hukum. Hal ini dapat terjadi karena hakim, dalam hukum kita, selain menjadi corong peraturan perundangundangan juga diberi keleluasaan untuk membuat terobosan hukum dalam pertimbangan-pertimbangan dan putusan-putusannya. Putusan hakim ini yang kemudian menjadi yurisprudensi yang dapat menjadi fenomena. Akan tetapi pada kenyataannya berdasarkan hasil wawancara hakim, hakim tidak dapat memberikan vonis maksimal dikarenakan cukup dengan dipenjara dan dibina. hakim sekarang lebih menjalankan fungsi sebagai corong undang-undang, sedangkan untuk fungsinya yang satu lagi, yaitu sebagai penghasil yurisprudensi, masih sangat kurang. Apabila hakim berani membuat terobosan dalam hal putusan perkara yang menyangkut perempuan dengan perspektif gender atau minimal berperspektif korban, akan dapat membawa angin baru bagi perkembangan dunia pengadilan. Selain itu, juga akan membawa harapan baru bagi perempuan-perempuan pencari keadilan.

2. Kebijakan perlindungan korban perkosaan dalam hukum positif Indonesia selama ini belum terlaksana dengan baik, masalah kejahatan selalu difokuskan pada apa yang dapat dilakukan terhadap pelaku tindak pidana. Perlindungan korban hanya diartikan secara tidak langsung dengan pencegahan kejahatan, yang seolah sudah tercapai bila pelakunya telah dipidana. Berdasarkan hasil dari wawancara yaitu;

a) Polisi lebih memprioritaskan dalam penanganan kasus dan melindungi hakhak korban perkosaan;

b) Jaksa untuk kasus perkosaan saksi korban selalu didahulukan dengan kasus lain dan menuntut dengan tuntutan maksimal terhadap pelaku; 
c) Dalam melindungi saksi korban didalam persidangan hakim memprioritaskan korban agar korban tidak mengalami trauma yang mendalam dan menghukum pelaku dengan pidana penjara agar membuat jera terhadap pelaku. Adapun saran dalam pembahasan ini adalah :

1. Dalam menjatuhkan sanksi pidana pada pelaku tindak pidana perkosaan seharusnya hakim memberikan hukuman yang maksimal agar dapat memberikan efek jera terhadap pelaku sehingga tidak terjadi lagi kasus-kasus perkosaan dengan mempertimbangkan dampak atau akibat tindak pidana tersebut bagi korban;

2. Dalam hal ini pembuat undang- undang harus dapat menghasilkan produk undang-undang dengan berkualitas serta instansi pemerintah harus memberikan sarana dan prasarana kepada aparat penegak hukum agar didalam kinerjanya dapat memberikan kontribusi secara maksimal. Penugasan polisi, baik polisi laki-laki maupun polwan di kepolisian hendaknya selain untuk membuat korban yang kebanyakan berjenis kelamin perempuan merasa nyaman melapor juga disertai dengan pembekalan pelatihan gender. Jaksa Penuntut Umum (JPU) didalam proses penuntutan harus mengupayakan tuntutan maksimal. Hakim dalam memvonis pelaku perkosaan seharusnya memberikan vonis maksimal dan melindungi korban untuk mendapatkan perlindungan hukum yang seadil-adilnya. 


\section{DAFTAR PUSTAKA}

Achmad Rifai. 2011. Penemuan Hukum Oleh Hakim Dalam Perspektif Hukum Progresif. Jakarta. Sinar Grafika.

Dadang Hawari. 2011. Psikapatologi Kejahatan Seksual. Jakarta. Fakultas Kedokteran Universitas Indonesia. Darmoko Yuti Witanto, Arya Putra Negara Kutawaringin. 2013. Bandung. Diskresi Hakim. CVAlfabeta.

Mien Rukmini. 2006. Bandung. Aspek Hukum Pidana dan Kriminologi, PT Alumni. M Natsir Asnawi. Yogyakarta.Hermeneutika Putusan Hakim, UII Press.

Soerjono Soekanto. 2013. Jakarta. Faktor-faktor yang Mempengaruhi Penegakan Hukum, PT. Raja Grafindo Persada.

Undang- undang Nomor 48 Tahun 2009 tentang Kekuasaan Kehakiman UndangUndang No 13 Tahun 2006 tentang Perlindungan Saksi dan Korban 